\title{
Expression of genes involved in neurogenesis, and neuronal precursor cell proliferation and development: Novel pathways of human ovarian granulosa cell differentiation and transdifferentiation capability in vitro
}

\author{
MACIEJ BRAZZERT ${ }^{1}$, WIESŁAWA KRANC ${ }^{2}$, PIOTR CELICHOWSKI ${ }^{3}$, MAURYCY JANKOWSKI $^{2}$, \\ HANNA PIOTROWSKA-KEMPISTY ${ }^{4}$, LESZEK PAWELCZYK ${ }^{1}$, MAŁGORZATA BRUSKA ${ }^{1}$, \\ MACIEJ ZABEL ${ }^{5,6}$, MICHAŁ NOWICKI ${ }^{3}$ and BARTOSZ KEMPISTY ${ }^{2,3,7}$ \\ ${ }^{1}$ Division of Infertility and Reproductive Endocrinology, Department of Gynecology, \\ Obstetrics and Gynecological Oncology, Poznań University of Medical Sciences, 60-535 Poznań; \\ Departments of ${ }^{2}$ Anatomy, and ${ }^{3}$ Histology and Embryology, Poznań University of Medical Sciences, \\ 60-781 Poznań; ${ }^{4}$ Department of Toxicology, Poznań University of Medical Sciences, 60-631 Poznań; \\ ${ }^{5}$ Division of Histology and Embryology, Department of Human Morphology and Embryology, \\ Wrocław Medical University, 50-368 Wrocław; ${ }^{6}$ Division of Anatomy and Histology, \\ University of Zielona Góra, 65-046 Zielona Góra, Poland; ${ }^{7}$ Department of Obstetrics and Gynecology, \\ University Hospital and Masaryk University, 62500 Brno, Czech Republic
}

Received June 19, 2019; Accepted December 10, 2019

DOI: $10.3892 / \mathrm{mmr} .2020 .10972$

\begin{abstract}
The process of neural tissue formation is associated primarily with the course of neurogenesis during embryonic life. The source of neural-like cells is stem cells, which, under the influence of appropriate differentiating factors, may differentiate/transdifferentiate towards a neural-like lineage. The present study suggested that, under long-term in vitro culture conditions, human ovarian granulosa cells (GCs), obtained from granulosa-rich follicular fluid, acquired new properties and expressed genes characteristic of the ontological groups 'neurogenesis' (GO:0022008), 'neuronal precursor cell proliferation' (GO:0061351) and 'nervous system development' (GO:0007399), which are closely related to the formation of neurons. The present study collected GCs from 20 women referred for the procedure of in vitro fertilization. Cells were maintained in long-term in vitro culture for 30 days, and RNA was isolated after 1, 7, 15 and 30 days of culture. The expression profile of individual genes was determined using the Affymetrix microarray method. The 131 genes with the highest expression change in relation to day 1 of culture were
\end{abstract}

Correspondence to: Dr Bartosz Kempisty, Department of Anatomy, Poznań University of Medical Sciences, 6 Święcickiego St., 60-781 Poznań, Poland

E-mail: bkempisty@ump.edu.pl

Key words: human granulosa cells, in vitro culture, differentiation, neural precursor cell proliferation then selected; the 10 most affected genes found to be primarily involved in nerve cell formation processes were chosen for consideration in this study: CLDN11, OXTR, DFNA5, ATP8B1, ITGA3, CD9, FRY, NANOS1, CRIMI and NTN4. The results of the present study revealed that these genes may be considered potential markers of the uninduced differentiation potential of GCs. In addition, it was suggested that GCs may be used to develop a cell line showing neuronal characteristics after 30 days of cultivation. In addition, due to their potential, these cells could possibly be used in the treatment of neurodegenerative diseases, not only in the form of 'cultured neurons' but also as producers of factors involved in the regeneration of the nervous system.

\section{Introduction}

The main function of ovarian granulosa cells (GCs) under physiological conditions is maintenance of the proper courses of folliculogenesis and oogenesis (1). In recent years, it has been demonstrated that human (h)GCs exhibit stem-like properties under conditions of long-term in vitro culture; therefore, they can differentiate into other cell types, such as osteoblasts, chondrocytes and muscle cells, under the influence of appropriate factors (2-4). A number of previous studies seem to suggest that GCs may also differentiate towards neural cells, despite the lack of any obvious link between these two cell types (5).

For a number of years, it was thought that the process of neurogenesis occurs only during embryonic and perinatal stages in mammals (6). Neurogenesis is defined as the process of functional neuron generation from precursor cells (7). 
During embryogenesis, the neural plate is formed, with its invaginations built from neuroepithelium. In subsequent stages of development, the neuroepithelium lines the inner layer of the neural tube, which gives rise to specific parts of the central nervous system. A characteristic feature of neuroepithelial cells is the ability to proliferate rapidly, resulting in separation of the sub-ventricular zone, which is the center of the brain ventriculi. The sub-ventricular zone contains numerous multipotent stem cells that are capable of transforming into neuron, astrocyte or oligodendrocyte progenitors (8). In the subsequent stages of brain development, neuroblasts are transformed into proneurons that move along radial astrocytes to the developing brain and spinal cord (9). Neurons of the peripheral nervous system arise from multipotent neural crest cells that migrate to target sites in an intercellular manner. At the destination, one neuronal tip becomes the next axon with the growth cone at the end. This cone has the ability to move in a quadriplegic motion towards the innervated organ. The complex process of neurogenesis depends on a number of factors, including the key role played by proteins belonging to the transforming growth factor $\beta$ (TGF $\beta$ ) family $(10,11)$.

One of the main goals of numerous research groups is the production of stable, functional neural cell lines that may be used to restore damage to the nervous system. In recent years, a number of attempts have been made to differentiate cells of stem-like potential towards neural lineage (5). These studies primarily used induced pluripotent stem cells (iPSCs) (12-14). Despite the difficulties, an increasing number of scientists are trying to find more sources of functional nerve cells (15-18). The search has moved away from the model based on cells taken from the embryo, as well as iPSCs, as this is considered an unstable model that exhibits a tendency towards tumorigenesis (19). New research focuses primarily on the reprogramming of stem-like somatic cells towards neurons.

There are a number of reports on the possibility of differentiation of mesenchymal stem cells towards neural stem cells $(5,20,21)$. Herman et al (20) was the first to present six protocols describing the reprogramming of bone marrow-derived human mesenchymal stem cells into neural stem cells. The process of this differentiation was possible by adding appropriate growth factors including brain-derived neurotrophic factor, platelet-derived growth factor, epidermal growth factor, fibroblast growth factor 2 and retinoic acid to the culture medium $(14,20)$. Another important model for obtaining neuronal cells is the transdifferentiation of somatic cells. Transdifferentiation is the reprogramming of somatic cells into another cell type, omitting the pluripotent stem cell stage. Transdifferentiation of somatic cells towards neurons seems to be particularly important. This method could become a novel strategy in acquiring neural cells, creating new treatment options for neurodegenerative diseases, and injuries to the central or peripheral nervous system (22). Recent studies have indicated that stem cells could become a tool for the effective treatment of neurological conditions (23-25). The use of stem cells can have a number of positive effects not necessarily associated with the artificial growth of new nerves. Mesenchymal stem cells in particular could be used to treat a number of neurodegenerative diseases, including Parkinson's disease, Alzheimer's disease and age-related macular degeneration, as well as traumatic brain injury and glioblastoma $(24,26)$.
Parkinson's disease manifests as a movement disorder due to loss of the substantia nigra dopaminergic neurons. In recent years, one of the most promising tools for effective treatment of this disease is based on the application of stem cells within the striatum (27). Stem cell therapy has also been used to treat stroke. Administration of stem cells within the first $24 \mathrm{~h}$ significantly increases the chances of patient recovery (28). In addition, cell therapy has an immunosuppressive and angiogenic effect; therefore, patients have improved health after the application of stem cells.

Another important issue, the mechanisms of which are not yet fully elucidated, is neurogenesis in adult mammals. For a long time, studies have indicated that new neurons are formed in the subgranular zone of the dentate gyrus of the mammalian hippocampus $(29,30)$ during learning, remembering or stress (31). Neurogenesis in adults is often discussed and it is believed that $\sim 700$ new neurons are created every day in the cusp of the human hippocampus $(32,33)$, while other studies have suggested that the neurogenesis process decreases with age $(34,35)$. It is suggested that the number of developing progenitor cells in the dentate gyrus drops sharply in the first year of life, as in healthy adults and patients with neurological pathology (epilepsy) no 'young' neurons have been detected in the hippocampal dentate gyrus (30). A previous rodent study indicated that mice maintained in a sensory enriched environment exhibited significantly more new neurons in the hippocampus than mice bred in cages (36).

The main objective of the present study was to identify the potential molecular markers characteristic of GC differentiation, and to develop a cell line possessing neuronal characteristics after 30 days of cultivation. The new properties of hGCs may also be used in the context of reconstruction of tissues following injury. In the present study, the most important finding was the identification of genes that perform a large role in the process of nerve cell formation during long-term in vitro culture. This knowledge might serve as a basic molecular entry into further in vitro and clinical studies.

\section{Materials and methods}

Previous work. Part of the materials and methods is based on other publications from the same research team, presenting results from the cycle of studies related to human ovarian GCs (37-41).

Patient clinical evaluations and GC collection. A total of 20 female patients (18-40 years; mean age, 27 years) assigned to the procedure of in vitro fertilization (IVF) at the Division of Infertility and Reproductive Endocrinology, Poznań University of Medical Sciences (Poznań, Poland) qualified for the present study. Patients were recruited between May 2017 and August 2019. Patients underwent controlled ovarian hyperstimulation with human recombinant follicle-stimulating hormone (rFSH; Gonal-F ${ }^{\circledR}$; Merck KGaA) and highly purified human menopausal gonadotropin (hMG-HP; Menopur ${ }^{\circledR}$; Ferring B.V.) and gonadotropin-releasing hormone (GnRH) antagonist (Cetrotide ${ }^{\circledR}$; Merck KGaA). Ovulation was induced by subcutaneous injection of 6,500 IU human chorionic gonadotropin (hCG; Ovitrelle ${ }^{\circledR}$; Merck KGaA). The doses 
of gonadotropins and GnRH antagonist were controlled and recorded for every patient. The follicular fluid (FF) containing oocytes and GCs was collected and transferred to a qualified embryologist who extracted all oocytes from the fluid and passed it on to the further stages of IVF. At this point, it was re-verified that FF did not contain oocytes. Subsequently, the GC-containing FF (this sample is usually discarded at this stage) was transferred for further laboratory testing. The FF containing GCs was collected during transvaginal ultrasound-guided oocyte pickup, $36 \mathrm{~h}$ after administration of hCG. GCs suspended in FF were obtained from follicles with a diameter $>16 \mathrm{~mm}$.

The exclusion criteria for the study were: i) A potential risk of inadequate ovarian stimulation according to the Bologna criteria of poor ovarian responders, published by the European Society of Human Reproduction and Embryology in 2011 (42); ii) serum antimullerian hormone $0.7 \mathrm{ng} / \mathrm{ml}$ as a cut-off value; iii) patients with a serum level of FSH $>15 \mathrm{mU} / \mathrm{ml}$ on the 2nd-3rd day of the cycle; iv) patients with polycystic ovary syndrome; or v) patients with endometriosis. The present study was approved by resolution 558/17 of the Poznań University of Medical Sciences Bioethical Committee. All participating patients were informed about the course of the study and expressed their written consent to use the material collected from them during the IVF procedure.

Long-term primary in vitro cell culture. The GC-containing FF was washed twice using Dulbecco's phosphate-buffered saline (Sigma-Aldrich; Merck $\mathrm{KGaA}$ ) and centrifuged at $200 \mathrm{x} \mathrm{g}$ for $10 \mathrm{~min}$ at room temperature. The culture medium consisted of Dulbecco's modified Eagle's medium (Sigma-Aldrich; Merck GaA), 2\% fetal bovine serum (Sigma-Aldrich; Merck KGaA), 4 mM L-glutamine (stock 200 mM; Gibco; Thermo Fisher Scientific, Inc.), $10 \mathrm{mg} / \mathrm{ml}$ gentamicin (Gibco; Thermo Fisher Scientific, Inc.), $10,000 \mathrm{U} / \mathrm{ml}$ penicillin and 10,000 $\mu \mathrm{g} / \mathrm{ml}$ streptomycin (Gibco; Thermo Fisher Scientific, Inc.). GCs were cultivated at $37^{\circ} \mathrm{C}$ under aerobic conditions $\left(5 \% \mathrm{CO}_{2}\right)$. The cultures used samples in which necrotic and apoptotic cells accounted for $<5 \%$. Once adherent cells were $>90 \%$ confluent, they were detached with $0.05 \%$ trypsin-EDTA (Gibco; Thermo Fisher Scientific, Inc.) for 1-3 min and counted using a fluorescence automatic cell counter (ADAM-MC; NanoEnTek America, Inc.). GCs were then cultivated for 30 days; total RNA was isolated after 1, 7, 15 and 30 days $(38,39,43)$. The medium was replaced every $72 \mathrm{~h}$. Cell morphology was observed after $1,7,15$ and 30 days of culture under an inverted light microscope (Olympus IXC73; Olympus Corporation).

Total RNA isolation. Total RNA was isolated after 1, 7, 15 and 30 days of culture. The Chomczyński-Sacchi method was used for total RNA extraction (44). The GCs, after trypsin treatment, were suspended in a 1-ml mixture of guanidine thiocyanate and phenol in monophase solution (TRI Reagent ${ }^{\circledR}$; Sigma-Aldrich; Merck KGaA); 1 ml TRI Reagent ${ }^{\circledR}$ was used to lyse $5-10 \times 10^{6}$ cells, with subsequent storage of the samples at $-80^{\circ} \mathrm{C}$. After thawing, $0.2 \mathrm{ml}$ chloroform per $\mathrm{ml}$ TRI Reagent ${ }^{\circledR}$ was added to the samples, which were then gently mixed (15 sec), and left to stand for $15 \mathrm{~min}$ at room temperature. After centrifugation (12,000 x g, $15 \mathrm{~min}$, room temperature), three phases were visible: Red organic phase (containing protein), interphase (containing DNA) and colorless upper phase (containing RNA). The aqueous phase that contained the RNA was precipitated with $0.5 \mathrm{ml}$ 2-propanol (cat. no. I9516; Sigma-Aldrich; Merck KGaA) per ml TRI Reagent ${ }^{\circledR}$ and incubated for $10 \mathrm{~min}$ at room temperature. Finally, the RNA pellet was washed with $75 \%$ ethanol. The resulting RNA was used for further analysis. The total mRNA was determined from the optical density at $260 \mathrm{~nm}$, and the RNA purity was estimated using the 260/280 $\mathrm{nm}$ absorption ratio (NanoDrop spectrophotometer; NanoDrop; Thermo Fisher Scientific, Inc.). Only samples with a 260/280 absorbance ratio $>1.8$ were used in the present study.

Microarray expression analysis. Total RNA (100 ng) from each pooled sample was subjected to two rounds of sense cDNA amplification (Ambion WT Expression kit; Thermo Fisher Scientific, Inc.), according to the manufacturer's protocol. The obtained cDNA was used for biotin labeling and fragmentation using the Affymetrix GeneChip WT Terminal Labeling and Hybridization kit (Affymetrix; Thermo Fisher Scientific, Inc.). Biotin-labeled fragments of cDNA $(5.5 \mu \mathrm{g})$ were hybridized to the Affymetrix Human Genome U219 Array (HgU 219; $48^{\circ} \mathrm{C} / 20 \mathrm{~h}$; Affymetrix; Thermo Fisher Scientific, Inc.). Microarrays were then washed and stained according to the technical protocol using the Affymetrix GeneAtlas Fluidics Station (Affymetrix; Thermo Fisher Scientific, Inc.). The array strips were scanned using the Imaging Station of the GeneAtlas system (Affymetrix; Thermo Fisher Scientific, Inc.). Preliminary analysis of the scanned chips was performed using Affymetrix GeneAtlas Operating Software v. 2.0.0.460 (Affymetrix; Thermo Fisher Scientific, Inc.). The quality of gene expression data was confirmed according to the quality control criteria provided by the software. The obtained CEL files were imported into downstream data analysis software $(38,45)$.

Reverse transcription-quantitative $(R T-q) P C R$. RT-qPCR was performed to validate microarray results, using the same cDNA samples. A total of 20 genes were selected from the 131 selected genes: 10 represent the highest change in expression, and 10 represent the lowest change in expression, but all 20 had been upregulated in relation to day 1 of primary culture. Each reaction was repeated three times, with three replicates per group. For RT, $1 \mu$ g each RNA sample was used. RT was conducted based on the protocols and reagents of the RT $^{2}$ First Stand kit (cat. no. 330401; Qiagen, Inc.), using a Veriti 96-well Thermal Cycler (Applied Biosystems; Thermo Fisher Scientific, Inc.). PCR was performed using the Light Cycler $^{\circledR} 96$ (Roche Diagnostics GmbH), RT ${ }^{2}$ SYBR Green ROX qPCR Master Mix (Qiagen, Inc.) and sequence-specific primers (Table I). The reaction cocktail used for the test contained $3 \mu \mathrm{l}$ nuclease-free water (Invitrogen; Thermo Fisher Scientific, Inc.), $5 \mu \mathrm{l} \mathrm{RT}{ }^{2}$ SYBR Green ROX qPCR Master Mix (Qiagen, Inc.), $0.5 \mu \mathrm{l}$ forward primers, $0.5 \mu \mathrm{l}$ reverse primers and $1 \mu \mathrm{l} \mathrm{cDNA}$. GAPDH, $\beta$-actin $(A C T B)$ and hypoxanthine phosphoribosyltransferase 1 (HPRT1) were used as reference genes. Thermocycling conditions were as follows: Preincubation at $37^{\circ} \mathrm{C}$ for $30 \mathrm{sec} ; 3$-step amplification $\left(95^{\circ} \mathrm{C}\right.$ for $15 \mathrm{sec}, 58^{\circ} \mathrm{C}$ for $15 \mathrm{sec}, 72^{\circ} \mathrm{C}$ for $15 \mathrm{sec}$ ) for 45 cycles; 
Table I. Oligonucleotide sequences of primers used for reverse transcription-quantitative polymerase chain reaction analysis.

\begin{tabular}{|c|c|c|}
\hline Gene & Primer sequences $\left(5^{\prime}-3^{\prime}\right)$ & $\begin{array}{c}\text { Product } \\
\text { size } \\
\text { (bp) }\end{array}$ \\
\hline \multirow[t]{2}{*}{ NTN4 } & F: GGCCTGGAAGATGATGTTGT & 234 \\
\hline & R: TTGAGGCTCTTCGTTCAGGT & \\
\hline \multirow[t]{2}{*}{ CRIMI } & F: GGAAGGAGAAACGTGGAACA & 247 \\
\hline & R: GTCAGGCTTCCAGGACTCAG & \\
\hline \multirow{2}{*}{ NANOS1 } & F: GCTCCTGGAACGACTACCTG & 209 \\
\hline & R: GTCGTCGTCCTCGTCGTAGT & \\
\hline \multirow[t]{2}{*}{$F R Y$} & F: CCAGCACAGTGACCTCTCAA & 232 \\
\hline & R: AACAAGGACGTTGGAGTTGG & \\
\hline \multirow[t]{2}{*}{$C D 9$} & F: TTGGTGATATTCGCCATTGA & 160 \\
\hline & R: ACGCATAGTGGATGGCTTTC & \\
\hline \multirow[t]{2}{*}{ ITGA3 } & F: GCCTGCCAAGCTAATGAGAC & 247 \\
\hline & R: AGAAGCTTTGTAGCCGGTGA & \\
\hline \multirow[t]{2}{*}{$A T P 8 B 1$} & F: TGCATACGAGGATTGGTTCA & 189 \\
\hline & R: ACCCCATGCAACAAGCTTAC & \\
\hline \multirow[t]{2}{*}{ DFNA5 } & F: AGGTGGCTTCGAGAACAAGA & 234 \\
\hline & R: AATAGGACCGCCTGGAAGAT & \\
\hline \multirow[t]{2}{*}{ OXTR } & F: TTCTTCGTGCAGATGTGGAG & 234 \\
\hline & R: GGACGAGTTGCTCTTTTTGC & \\
\hline \multirow[t]{2}{*}{$C L D N 11$} & F: CTGGTGGACATCCTCATCCT & 190 \\
\hline & R: CCAGCAGAATGAGCAAAACA & \\
\hline \multirow[t]{2}{*}{$R P M 1$} & F: GGAGGAATTGGTGTTGCTGT & 235 \\
\hline & R: GCTGCTCTTCCTTTCCTGTG & \\
\hline \multirow[t]{2}{*}{$S R G A P 2$} & F: ACTAAAGGAGGCGGAGAAGC & 220 \\
\hline & R: GTACTCATTCCGGGCTTTGA & \\
\hline \multirow[t]{2}{*}{ LRFN4 } & F: GGACTGGTGGACCTGACACT & 194 \\
\hline & R: GATGAGGTGCTGCAGATTGA & \\
\hline \multirow[t]{2}{*}{ INPP5J } & F: TTCAACTTCGTGCTGGTGAG & 248 \\
\hline & R: TTCAGGAAGCAGAGCATGTG & \\
\hline \multirow[t]{2}{*}{ RITAl } & F: CCCTCACACCAAGGAAGAAG & 204 \\
\hline & R: CTCTGTCTTGGAGGGACCAG & \\
\hline \multirow[t]{2}{*}{ PPP3CA } & F: TGCATCAATTCTTCGACAGG & 162 \\
\hline & R: AAGGCCCACAAATACAGCAC & \\
\hline \multirow[t]{2}{*}{ CTNND1 } & F: TCTGCCATAGCTGACCTCCT & 208 \\
\hline & R: GGAGTTCTGCTGTCCTCCTG & \\
\hline \multirow[t]{2}{*}{ CASP2 } & F: GACGCAGGATATTGGGAGTG & 170 \\
\hline & R: GGCAGCAAGTTGAGGAGTTC & \\
\hline \multirow[t]{2}{*}{$V I M$} & F: GAGAACTTTGCCGTTGAAGC & 199 \\
\hline & R: TCCAGCAGCTTCCTGTAGGT & \\
\hline \multirow[t]{2}{*}{ KIDINS220 } & F: CTGATGATAGCTGCCGAACA & 191 \\
\hline & R: GAGCTGTCCATCCTCCCATA & \\
\hline \multirow[t]{2}{*}{$R R M 1$} & F: GGAGGAATTGGTGTTGCTGT & 235 \\
\hline & R: GCTGCTCTTCCTTTCCTGTG & \\
\hline \multirow[t]{2}{*}{ GAPDH } & F:TCAGCCGCATCTTCTTTTGC & 90 \\
\hline & R:ACGACCAAATCCGTTGACTC & \\
\hline \multirow[t]{2}{*}{$\beta$-actin } & F:AAAGACCTGTACGCCAACAC & 132 \\
\hline & R:CTCAGGAGGAGCAATGATCTTG & \\
\hline HPRT1 & F:TGGCGTCGTGATTAGTGATG & 141 \\
\hline & R:ACATCTCGAGCAAGACGTTC & \\
\hline
\end{tabular}

F, forward; R, reverse. melting $\left(95^{\circ} \mathrm{C}\right.$ for $60 \mathrm{sec}, 40^{\circ} \mathrm{C}$ for $60 \mathrm{sec}, 70^{\circ} \mathrm{C}$ for $1 \mathrm{sec}, 95^{\circ} \mathrm{C}$ for $1 \mathrm{sec}$ ); cooling at $37^{\circ} \mathrm{C}$ for $30 \mathrm{sec}$. Gene expression was analyzed using the $2^{-\Delta \Delta \mathrm{Cq}}$ method. The qPCR primers were designed using Primer3Plus software (http://primer3plus. com/cgi-bin/dev/primer3plus.cgi).

Statistical analysis. All of the presented analyses and graphs of microarray expression were performed and generated using Bioconductor (v. 3.10; https://www.bioconductor.org/) and $\mathrm{R}$ programming language (v 3.5.1; www.r-project.org). Each CEL file was merged with a description file. In order to correct background, normalize and summarize results, the Robust Multiarray Averaging algorithm was used. To determine the statistical significance of the analyzed genes, moderated t-statistics from the empirical Bayes method were performed. The obtained P-value was corrected for multiple comparisons using Benjamini and Hochberg's false discovery rate. The selection of significantly altered genes was based on $\mathrm{P}<0.05$ and expression $>2$-fold. The differentially expressed gene list (separated for up- and downregulated genes) was uploaded to the Database for Annotation, Visualization and Integrated Discovery (DAVID, v 6.8) software to investigate their mutual relations (46-48). DAVID was used for extraction of the genes belonging to 'neurogenesis', 'neuronal precursor cell proliferation' and 'nervous system development' GO BP terms. Up- and downregulated gene sets were subjected to the DAVID search separately and only gene sets with adjusted $\mathrm{P}<0.05$ were selected.

Subsequently, mutual interactions between the genes belonging to the selected Gene Ontology (GO) biological process (BP) terms were investigated using the GOplot package (49). Finally, the functional interactions (FIs) between genes that belong to the chosen GO BP terms were investigated by REACTOME FIViz application in the Cytoscape 3.6.0 software (https://cytoscape.org/). The ReactomeFIViz application is designed to find pathways and network patterns related to cancer and other types of diseases. This application accesses the pathways stored in the Reactome database, allowing pathway enrichment analysis for a set of genes, visualizing hit pathways using manually laid-out pathway diagrams directly in Cytoscape, and investigating functional relationships among genes in hit pathways. The application can also access the Reactome FI network, a highly reliable, manually curated pathway-based protein FI network covering $>60 \%$ of human proteins. The results of the experiments refer to three separate biological replicates, and represent the average measurements (mean \pm standard error of mean) from each time period of the cell cultures and mRNA measurements, as determined by RT-qPCR. In the case of RT-qPCR, biological replicates were divided into three technical repetitions. As an internal control, HPRT1, GAPDH and ACTB were used, for which the levels of transcripts analyzed were standardized in each sample. Relative quantification was performed using the $2^{-\Delta \Delta \mathrm{Cq}}$ method to determine target cDNA quantification (50). Statistical analysis of the RT-qPCR results was performed for all samples considered separately (Student's t-test was corrected using Benjamini and Hochberg coefficient). $\mathrm{P}<0.05$ was considered to indicate a statistically significant difference. The analysis was performed using the Real Statistics Resource Pack for MS Excel 2016 (Microsoft Corporation). 


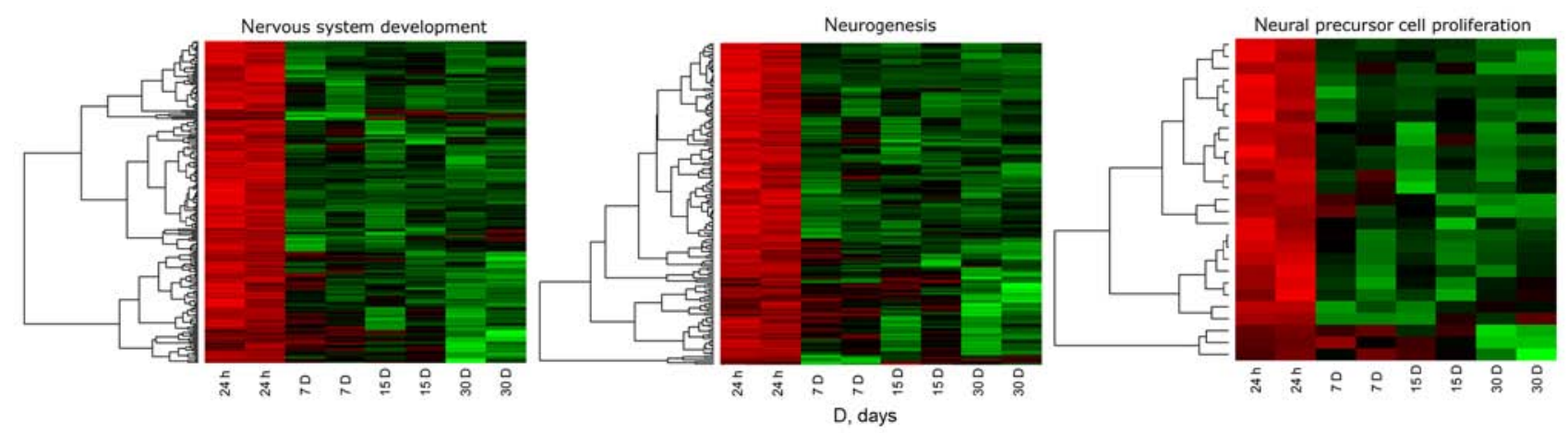

Figure 1. Heat map representation of differentially expressed genes belonging to the 'neurogenesis', 'neuronal precursor cell proliferation' and 'nervous system development' Gene Ontology biological process terms. Arbitrary signal intensity acquired from microarray analysis is represented by colors (green, higher expression; red, lower expression). Log 2 signal intensity values for any single gene were resized to $\mathrm{z}$-score scale (from -2 , the lowest expression to +2 , the highest expression for a single gene).

\section{Results}

Overview. Microarray analysis allows the identification of groups of genes related to the development of the nervous system and neurogenesis. Three ontological groups: 'neurogenesis', 'neuronal precursor cell proliferation' and 'nervous system development' were chosen. The microarray results provided 131 genes from three heat maps. The highest change in expression was demonstrated by claudin 11 (CLDN11), oxytocin receptor (OXTR), gasdermin E (DFNA5), ATPase phospholipid transporting 8B1 (ATP8B1), integrin subunit $\alpha 3$ (ITGA3), CD9, FRY microtubule binding protein $(F R Y)$, nanos C2HC-type zinc finger 1 (NANOSI), cysteine rich transmembrane BMP regulator 1 (CRIMI) and netrin 4 (NTN4). The first part of the results focuses on the 131 genes belonging to all three selected ontological groups. The second part of the results focuses on the genes with the highest change in expression.

Microarray analysis. Whole transcriptome profiling by Affymetrix microarray allowed the analysis of transcriptomic changes of the GCs during long-term in vitro culture after $24 \mathrm{~h}$ (1 day), 7, 15 and 30 days of culture. Using Affymetrix ${ }^{\circledR}$ Human HgU 219 Array, the expression levels of 22,480 transcripts were examined. Genes with fold change $>2$ and corrected $\mathrm{P}<0.05$ were considered as differentially expressed. This set of genes consisted of 2,278 different transcripts and is available as from the GEO database (https://www.ncbi.nlm. nih.gov/geo/query/acc.cgi?acc=GSE129919). The DAVID software analysis demonstrated that differentially expressed genes belong to $582 \mathrm{GO}$ groups.

Fig. 1 shows the hierarchical clustering of all genes belonging to the selected ontological groups, presented as heat maps. The heat maps indicate a large number of genes involved in neurogenesis-related processes, and show the levels of expression of a given gene at particular time intervals of long-term primary in vitro culture. The gene symbols, fold changes in expression, Entrez gene IDs and corrected $\mathrm{P}$-values of the genes are shown in Table SI. The enrichment of each GO BP term was calculated as a z-score and shown on a circle diagram (Fig. 2). The aforementioned circle graph combines data on the expression of all genes belonging to the listed ontological groups and the enrichment of gene annotations. It also demonstrates the spread of gene expression data.

In the GO database, genes that are associated with one particular GO term can also belong to other GO term categories. For this reason, the gene intersections between the selected GO BP terms were explored. The next stage of statistical analysis was focused on analyzing the relationships between genes with the highest change in expression, closely related to the process of neurogenesis. From this group, eight genes were selected, based on their assumed importance in the process of interest. The relation between those GO BP terms was presented as a circle plot (Fig. 3) as well as heat maps (Fig. 4).

Finally, the FIs between chosen genes were investigated with REACTOME FIViz application in Cytoscape 3.6.0 software. This statistical analysis concerned the interaction between genes involved in neurogenesis-related processes. All genes belonging to selected ontological groups were considered in this study. The results are shown in Fig. 5. Notably, all of the genes were involved in interaction with other representatives of the analyzed group. There were four larger groups of interacting genes, as well as several genes that only exhibited singular interactions.

$R T-q P C R$ results. The 20 genes with increased expression were subjected to validation and 10 of these genes exhibited the highest changes in expression compared to day 1 of primary culture (CLDN11, OXTR, DFNA5, ATP8B1, ITGA3, CD9, FRY, NANOSI, CRIM1 and NTN4). The remaining 10 genes (RRM1, SRGAP2, LRFN4, INPP5J, RITA1, PPP3CA, CTNND1, CASP2, VIM and KIDINS220) exhibited the lowest level of upregulation, being on the border of selection for this study with a fold change only slightly $>2$. As shown in Fig. 6 , the RT-qPCR method confirmed the direction of change in the expression of the top 10 genes with the highest transcript expression in microarray analysis in most of the cases, with the exception of CRIM1, which exhibited discrepancies at day 30. Differences in the scale of change are due to the sensitivity of the methods used. For some genes, the direction of change in expression was not confirmed by RT-qPCR (Fig. 6). This discrepancy can be explained in two ways: On one hand, this may be due to the fact that the RT-qPCR method is much more sensitive to quantitative changes, on the other hand it may indicate that selected genes exhibited very low upregulation of 
D7/D1

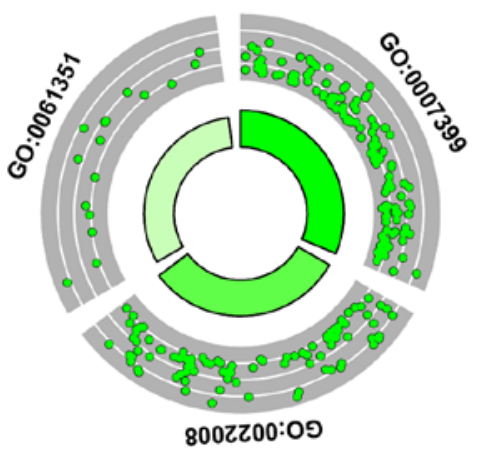

D15/D1

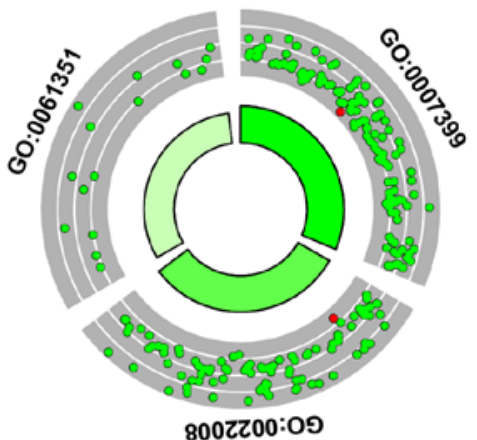

D30/D1

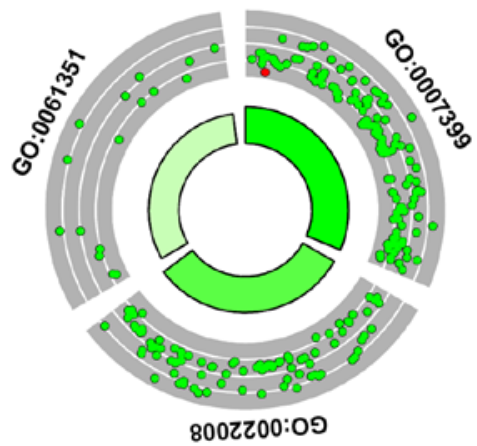

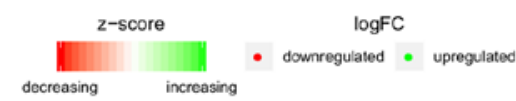

\begin{tabular}{|c|c|}
\hline ID & Description \\
\hline GO:0007399 & Nervous system development \\
\hline GO:0022008 & Neurogenesis \\
\hline GO:0061351 & Neural precursor cell proliferation \\
\hline
\end{tabular}

Figure 2. Circle plots showing the z-scores of differentially expressed genes associated with the chosen GO BP terms from the heat maps. The outer circle shows a scatter plot of the fold change in expression of the assigned genes for each term. Red circles represent downregulation and green circles represent upregulation. The inner circle shows the z-score of each GO BP term. The width of each bar corresponds to the number of genes within the GO BP term, with the color indicating the z-score. BP, biological process; FC, fold change; GO, Gene Ontology.

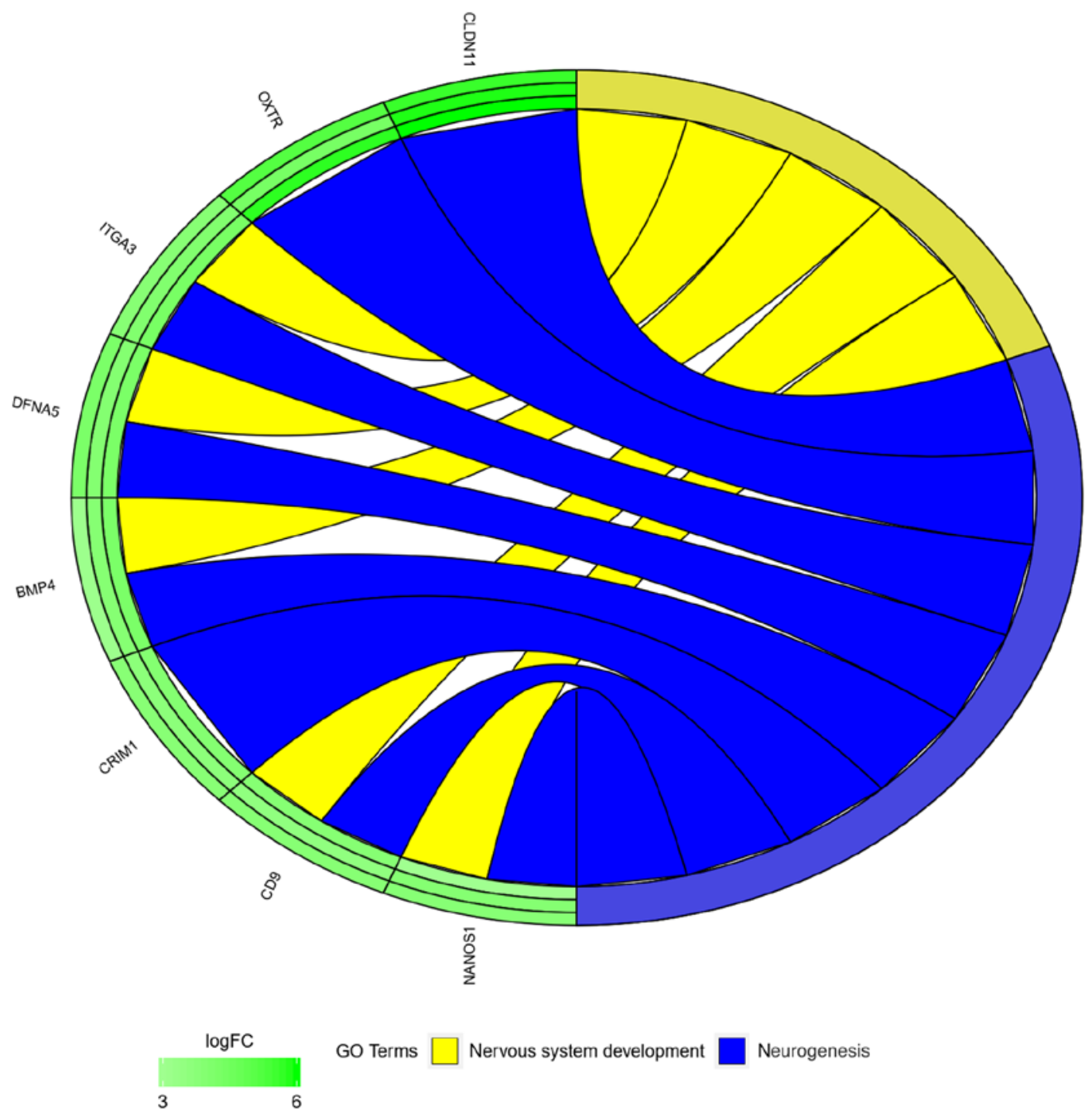

Figure 3. Representation of the mutual relationship between 'neurogenesis', and 'nervous system development' GO biological process terms. The ribbons indicate which gene belongs to which categories. The genes were sorted by logFC from most to least changed gene. FC, fold change; GO, Gene Ontology. 


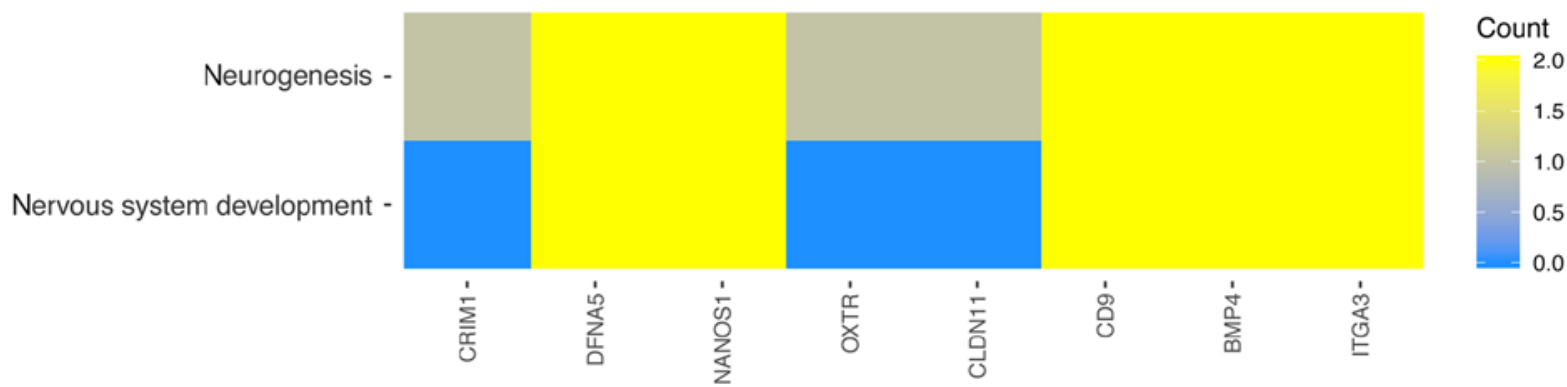

Figure 4. Heat map showing the gene occurrence in 'neurogenesis', and 'nervous system development' Gene Ontology process terms.

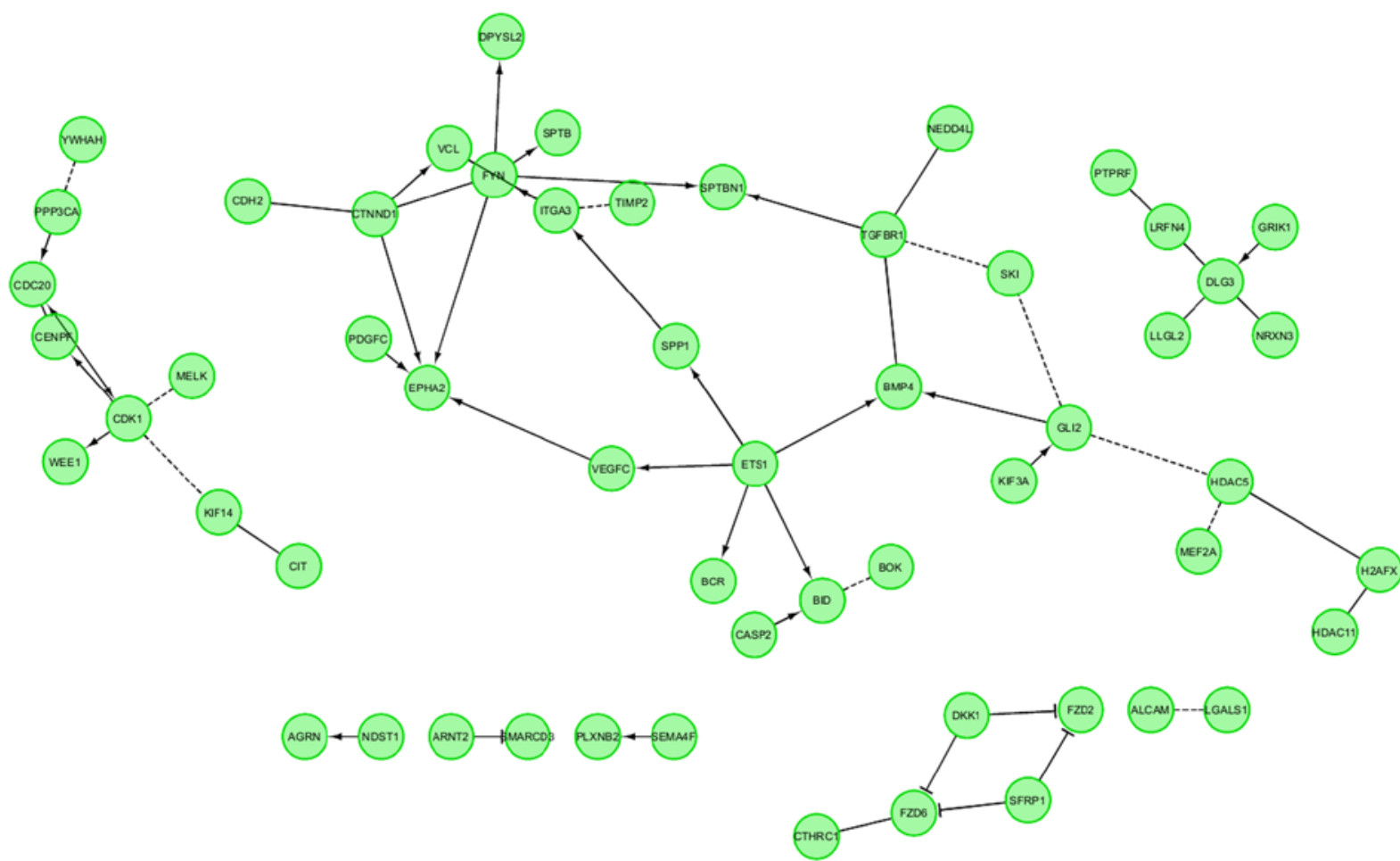

Figure 5. FI between chosen genes with the REACTOME FIViz application in Cytoscape 3.6.0 software. In the figure '->' stands for activating/catalyzing, '-l' for inhibition, '-' for FIs extracted from complexes or inputs, and '----' for predicted FIs. FI, functional interaction.

transcript levels during the microarray analysis. Such discrepancies confirm that whole transcriptomic screening requires extensive quantitative validation.

Cell morphology. Notably, it has been suggested that GCs exhibit morphology similar to that of nerve cells in long-term in vitro culture conditions and exhibit molecular markers characteristic of neuronal cells (51). The morphology of GCs in the present study also changed. Initially, the cells had a stellate shape, after which, they transformed (regardless of confluence) into spindle-shaped cells (Fig. 7). Such changes have also been confirmed in other studies $(37,39)$.

\section{Discussion}

In the present study, a group of genes responsible for processes associated with neurogenesis, nervous system development and neural precursor cell proliferation were selected for analysis during long-term in vitro culture of GCs. The results indicated that these cells have the potential to differentiate towards neurons, as they express neural-differentiation specific genes, providing further proof for their stem-like potential $(14,20)$. A number of studies have reported that it is possible to obtain neuronal-like cells during the differentiation/transdifferentiation of other cell types $(5,39,43,52)$. Notably, neural-like cells can be obtained through adipocyte differentiation. These adipocyte-derived cells of neural lineage exhibited high levels of CLDN11 (oligodendrocyte-specific protein), which is a marker of glial cells (53). The CLDN11 gene exhibited the highest expression at the individual time intervals in the present study. CLDNs are membrane proteins that belong to the peripheral myelin protein 22 superfamily. One of the most important functions of these membrane proteins is to co-create tight junction connections (54). The presence of CDLN proteins in epithelial cells and endothelium is regulated hormonally, and is also subject to changes depending on ovarian dysfunction (54). In addition, the administration of hormonal stimulation affects the expression of CLDN in 


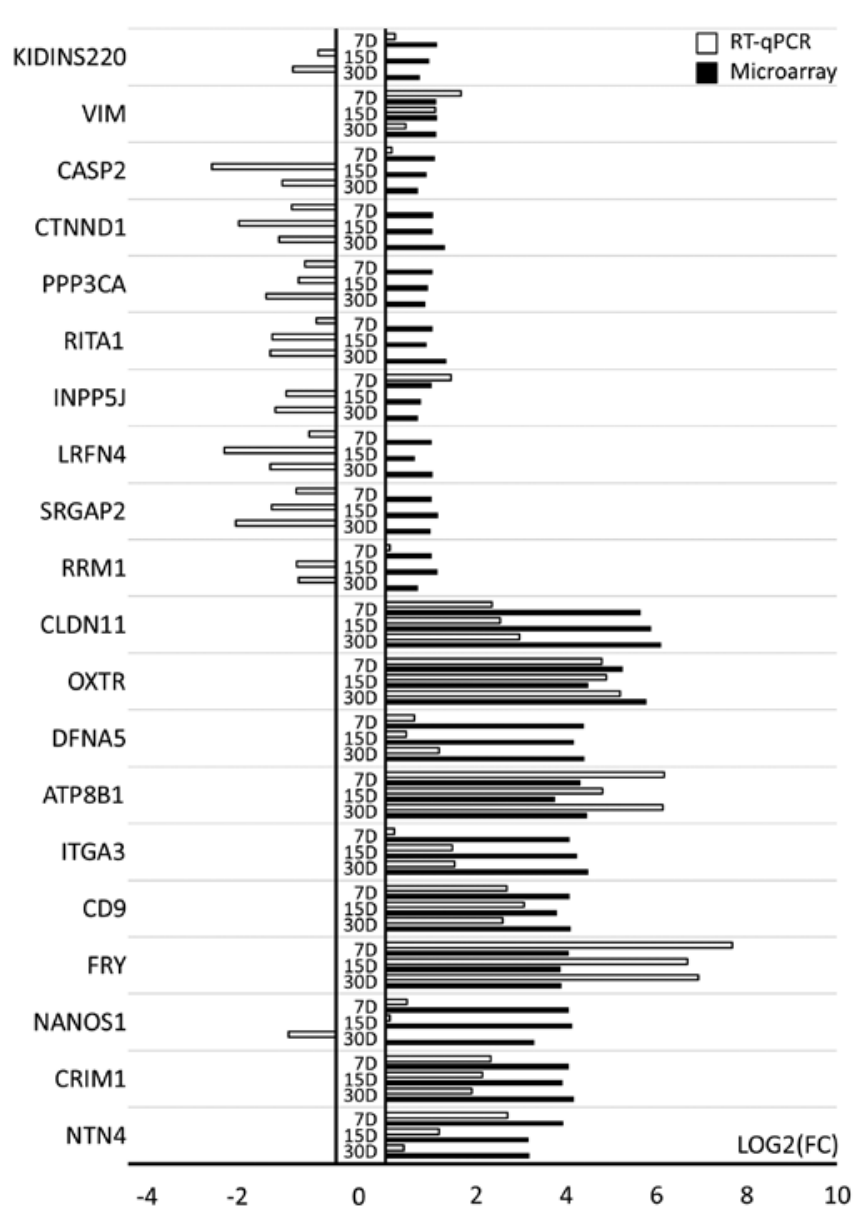

Figure 6. RT-qPCR results. Validation of gene expression has been presented in the form of a bar-graph. All FCs were validated in reference to the transcript levels on day 1 of in vitro culture. FC, fold change; RT-qPCR, reverse transcription-quantitative PCR.

the ovaries, with hCG administration causing an increase in the expression of $C L D N 11$ at the transcript level, which indicates the expression of this gene during ovulation (55). It is also believed that this gene may be involved in the growth of ovarian follicles in cattle (56). In addition, this gene is highly expressed in neurons (53).

Another gene that was highly expressed during the 30 days of in vitro culture was OXTR. In vivo, it is primarily associated with fertility and reproductive behavior (57). It has also been suggested that this gene is involved in the formation of the heart and cardiac muscle cells (58). Therefore, its expression has also been discussed in a previous study regarding the differentiation of GCs to myocardial cells (39). Many scientists believe that neurogenesis also occurs in adult mammals (59-64). Research by Lin et al (65) indicated that oxytocin may stimulate neurogenesis occurring in the hippocampal gyrus in adult humans. Oxytocin neurons located in the paraventricular nucleus connect directly to the hippocampus (65). Oxytocin is assumed to perform a key role in the neurogenesis of adult mammals, including humans (65). However, another study indicated that $O X T R$ is not expressed in neuronal progenitor cells derived from the subgranular dentate gyrus (66).

Another gene with high expression in this study was DFNA5. This gene encodes proteins located in a number of organs, including the cortex of the brain and the ovaries (67-70).
In the cortex, this gene is expressed at RNA and protein levels. A previous study by Croes et al (71) suggested that DFNA5 may be considered a breast cancer biomarker, as there are significant differences between the expression of DFNA5 in women with breast cancer and healthy controls. It has also been shown that the expression of this gene is influenced by the presence of the estrogen receptor (71). Other studies revealed that an increase in the expression DFNA5 may be affected by the hormonal stimulation of patients (72-74). Assou et al (72) indicated that DFNA5 expression is increased in cumulus cells obtained from patients following rFSH stimulation, compared to cells obtained following hMG-HP stimulation. These findings indicated that the high expression of DFNA5 detected in GCs in this study may be the result of stimulation with $\mathrm{rFSH}$. In the present study, patients were also stimulated with hMG-HP, so both substances may influence the aforementioned results. Previous research has indicated the possibility of the differentiation of GCs towards neurons. In addition, DFNA5 expression is also increased in another type of MSC, in bone marrow cells during their differentiation into neuronal cells $(73,74)$.

The ITGA3 gene, which encodes a protein from the integrin family, was also highly expressed in GCs in this study. Integrins, as the main extracellular matrix receptors, are poorly understood in the nervous system. Non-neural tissue is the subject of the majority of research into these proteins (75). It is well known that during embryonic development, integrins serve an important role in neurogenesis (76). The extracellular matrix and its receptors, which influence the process of nerve cell formation as well as synaptic connections, seem particularly important (75). Under physiological conditions, integrins have a role in the differentiation of individual GC populations during folliculogenesis and are also present in endometrial cells (77). The results of the present study suggested that the ITGA3 gene may be involved in the process of differentiation and formation of neuronal precursor cells. To the best of our knowledge, this study is the first to indicate this and this finding is not confirmed elsewhere in the literature.

In the present study, the CRIMI gene exhibited increased expression at particular time intervals of human GC culture, relative to the control (1st day of culture). Overexpression of CRIM1 in mice increased the activity of integrins (including ITGA1), and induced phosphorylation of focal adhesion kinase and ERK. It is suggested that this gene may participate in the formation of motor neurons and regulate their viability through interaction with various growth factors. Kolle et al (78) reported that development of the central nervous system is dependent on the CRIMI gene; CRIMI is expressed in early motor neurons as well as in the developing spinal cord. It is believed that CRIMI encodes a transmembrane protein that contains the sequence of the IGF binding protein. In addition, this transmembrane protein contains numerous cysteine-rich repeats $(78,79)$. It has also been suggested that this gene interacts with bone morphogenetic proteins (BMPs). The interaction between CRIM1 and BMP/TGF $\beta$ may be functionally important for the proper development of the central nervous system (78). In addition, it has been suggested that this gene is involved in the survival ability of motor neurons in the embryo and following injury in adult animals (80). 

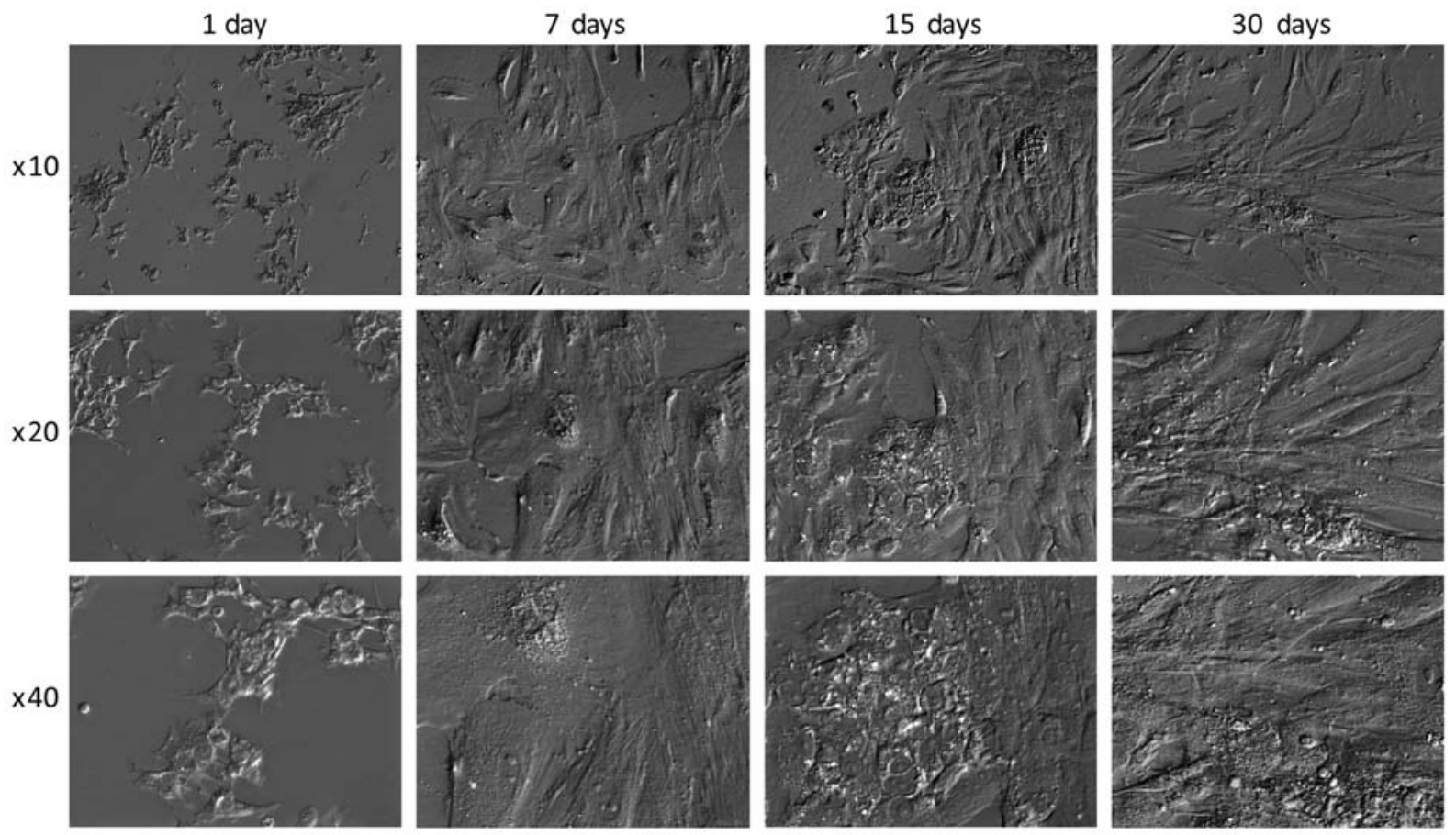

Figure 7. Morphology of human ovarian granulosa cells during 30 days long-term in vitro culture.

While not presented in detail in this study, as it was not one of the 10 genes that exhibited the biggest change in any direction, BMP4 was also differentially expressed in GC long-term in vitro culture. The protein encoded by this gene serves a number of functions during embryonic and postnatal development, including bone development, mineralization, neurogenesis, adipogenesis and ovarian primordial follicle development (81-83). Co-expression of this gene with other factors $(C R I M I)$ in this study suggests that long-term in vitro cultivation may result in the process of GC differentiation to neuronal cells. The presented results from our study (expression of CRIM1 and BMP4) suggested that GCs may have the potential to differentiate into neural-like cells.

Takao et al (84) suggested that the expression of genes responsible for integrin formation is correlated with the presence of CD9 on surface of the GCs. In the present study regarding GCs, CD9 and ITGA3 were highly upregulated, but correlation studies do not show any link between them (84). CD9 is a marker of mesenchymal stem cells; a previous report demonstrated that cells expressing this marker can differentiate towards neuronal cells and express neural cell-specific proteins (vimentin, glial fibrillary acidic protein, nuclear factor, neuron specific enolase and nestin) (85). CD9 is primarily found in stem cell exosomes, and a previous study revealed that exosomes can also serve an important role in neurogenesis and can function as information relays between stem and neural cells (86). These findings suggested that the presence of this marker in GCs may indicate their potential to differentiate into neural-like cells.

The studied cells also expressed the NANOS1 gene (87). NANOS1 is primarily responsible for the coding of proteins involved in the development of embryonic stem cells in one or both sexes of model organisms, such as Drosophila melanogaster $(88,89)$ or Caenorhabditis elegans $(90)$. The human equivalent of this gene exhibits a high expression in germinal stem cells (91), as well as in oocytes at various levels of maturity (92). In addition, high expression levels of this gene have been detected in the fetal brain (93), which is important with regards to the findings of the present study.

Through analysis of the obtained results and available literature, it was concluded that GCs may possess stem-like functions and might be capable of differentiating into neuronal cells under long-term in vitro cultures. This suggestion was supported by the high expression of genes associated with processes, such as neurogenesis, nervous system development and neural precursor cell proliferation. The present study was carried out at the transcriptome level. Obtained results, despite validation using quantitative methods, require confirmation at the protein level, as well as an analysis of factors released during the potential differentiation process. In addition, it should be noted that analysis of the GC transcriptome using microarrays is a largely qualitative method, which can be seen in the validation carried out by RT-qPCR. Variable results might be caused by differences in microarray probe and RT-qPCR primer design, and their specificity and responsiveness to particular transcript variants. They can also result from the potential interactions between cDNAs present in the analyzed samples, leading to false positive/negative results. This further emphasizes the need of protein validation of the results, which could also account for the processes that underlie the discrepancies between transcriptomic and proteomic results, including alternative splicing, selective translation and post transcriptional regulation processes.

In conclusion, the present study analyzed the expression profile of genes belonging to three ontological groups: 'neurogenesis' (GO:0022008), 'neuronal precursor cell proliferation' (GO:0061351) and 'nervous system development' 
(GO:0007399). The results appear to support the suggestion that GCs may be able to develop into a cell line showing neuronal characteristics after 30 days of cultivation, and may serve as a basic transcriptomic entry for further research that could fully confirm this ability. Given the proven plasticity of FF GCs in the context of the current trend to consider treatment of nervous system disorders with stem cells, GCs may be considered a promising tool in the treatment of these diseases, as they appear to exhibit significant stem-like properties. Hence, it is necessary to take into account the number of mechanisms triggered by the administration of stem cells, which can be beneficial when treating diseases, due to their anti-inflammatory or immunomodulatory effects. The results of the present study are a promising introduction to further research on the mechanisms and factors that result in the ability of the analyzed cells to express neuronal features. In the future, GCs could not only become a tool of direct neuronal regeneration but also a producer of factors that may find application in the treatment of neurodegenerative diseases. Our long-term project aims to examine the further molecular mechanisms associated with genes of interest, with next stages of research planned, in which the cells in the present study will be cultured with neural differentiation medium. Furthermore, the authors will aim to compare the transcriptome of GCs before and after exposure to neural differentiation medium.

\section{Acknowledgements}

Not applicable.

\section{Funding}

The present study was supported by the National Science Centre (grant no. 2018/31/B/NZ5/02475) and the Poznań University of Medical Sciences (grant no. 502-14-02227367-10694).

\section{Availability of data and materials}

The datasets used and/or analyzed during the current study are available from the corresponding author on reasonable request. In addition, the datasets generated and/or analyzed during the current study are available in the Gene Expression Omnibus repository, [https://www.ncbi.nlm.nih.gov/geo/query/acc. cgi?acc $=$ GSE129919].

\section{Authors' contributions}

MBra designed and performed the experiments, chose the models, prepared part of the medical methodology, and drafted and wrote parts of the manuscript. WK wrote parts of the manuscript, and prepared and validated the RNA isolation protocol. PC performed data analysis, prepared figures and wrote parts of the manuscript. MJ performed data analysis and language corrections. HPK was responsible for software, experimental design and model analysis. LP made substantial contributions to conception of experiments, revised it critically for important intellectual content. MBru supervised the project, provided technical advice and conducted analyses of the raw data. MZ revised the methodology, optimizing the methods of culture and analysis, and assisted in writing the manuscript. MN designed the methodology, and assisted in writing and revision of the manuscript. BK contributed to project supervision and design, revision of methodology, editorial supervision and major assistance. All authors approved the final article.

\section{Ethics approval and consent to participate}

This study has been approved with resolution 558/17 by Poznań University of Medical Sciences Bioethical Committee. All participating patients were informed about the course of the study and expressed their written consent to use the material collected from them during the IVF procedure.

\section{Patient consent for publication}

Not applicable.

\section{Competing interests}

The authors declare that they have no competing interests.

\section{References}

1. Rybska M, Knap S, Jankowski M, Jeseta M, Bukowska D, Antosik P, Nowicki M, Zabel M, Kempisty B and Jaśkowski JM: Characteristic of factors influencing the proper course of folliculogenesis in mammals. Med J Cell Biol 6: 33-38, 2018.

2. Dzafic E, Stimpfel M and Virant-Klun I: Plasticity of granulosa cells: On the crossroad of stemness and transdifferentiation potential. J Assist Reprod Genet 30: 1255-1261, 2013.

3. Brevini TAL, Pennarossa G, Rahman MM, Paffoni A, Antonini S, Ragni G, deEguileor M, Tettamanti G and Gandolfi F: Morphological and molecular changes of human granulosa cells exposed to 5-azacytidine and addressed toward muscular differentiation. Stem Cell Rev Reports 10: 633-642, 2014.

4. Kossowska-Tomaszczuk K, Pelczar P, Güven S, Kowalski J, Volpi E, De Geyter C and Scherberich A: A novel three-dimensional culture system allows prolonged culture of functional human granulosa cells and mimics the ovarian environment. Tissue Eng Part A 16: 2063-2073, 2010.

5. Kossowska-Tomaszczuk K, De Geyter C, De Geyter M, Martin I, Holzgreve W, Scherberich A and Zhang H: The multipotency of luteinizing granulosa cells collected from mature ovarian follicles. Stem Cells 27: 210-219, 2009.

6. Ming G and Song H: Adult neurogenesis in the mammalian central nervous system. Annu Rev Neurosci 28: 223-250, 2005.

7. Ming GL and Song H: Adult neurogenesis in the mammalian brain: Significant answers and significant questions. Neuron 70: 687-702, 2011.

8. Kriegstein A and Alvarez-Buylla A: The Glial nature of embryonic and adult neural stem cells. Annu Rev Neurosci 32: 149-184, 2009.

9. Pistorius LR: Imaging of the embryonic and fetal central nervous system. Facts Views Vis Obgyn 1: 66-71, 2009.

10. Liu A and Niswander LA: Bone morphogenetic protein signalling and vertebrate nervous system development. Nat Rev Neurosci 6: 945-954, 2005.

11. Rybska M, Knap S, Stefańska K, Jankowski M, ChamierGliszczyńska A, Popis M, Jeseta M, Bukowska D, Antosik P, Kempisty B, et al: Transforming growth factor (TGF)-is it a key protein in mammalian reproductive biology? Med J Cell Biol 6: 125-130, 2018.

12. D'Aiuto L, Zhi Y, Kumar Das D, Wilcox MR, Johnson JW, McClain L, MacDonald ML, Di Maio R, Schurdak ME, Piazza P, et al: Large-scale generation of human iPSC-derived neural stem cells/early neural progenitor cells and their neuronal differentiation. Organogenesis 10: 365-377, 2014. 
13. Denham M and Dottori M: Neural differentiation of induced pluripotent stem cells. Methods Mol Biol 793: 99-110, 2011

14. Samoilova EM, Kalsin VA, Kushnir NM, Chistyakov DA, Troitskiy AV and Baklaushev VP: Adult neural stem cells: Basic research and production strategies for neurorestorative therapy. Stem Cells Int 2018: 4835491, 2018.

15. Anchan R, Gerami-Naini B, Lindsey JS, Ho JW, Kiezun A, Lipskind S, Ng N, LiCausi JA, Kim CS, Brezina P, et al: Efficient differentiation of steroidogenic and germ-like cells from epigenetically-related iPSCs derived from ovarian granulosa cells. PLoS One 10: e0119275, 2015.

16. Son EY, Ichida JK, Wainger BJ, Toma JS, Rafuse VF, Woolf CJ and Eggan K: Conversion of mouse and human fibroblasts into functional spinal motor neurons. Cell Stem Cell 9: 205-218, 2011.

17. Miyoshi N, Ishii H, Nagano H, Haraguchi N, Dewi DL, Kano Y, Nishikawa S, Tanemura M, Mimori K, Tanaka F, et al: Reprogramming of mouse and human cells to pluripotency using mature microRNAs. Cell Stem Cell 8: 633-638, 2011.

18. Brouwer M, Zhou H and Nadif Kasri N: Choices for induction of pluripotency: Recent developments in human induced pluripotent stem cell reprogramming strategies. Stem Cell Rev Rep 12 54-72, 2016.

19. Attwood SW and Edel MJ: iPS-cell technology and the problem of genetic instability-can it ever be safe for clinical use? J Clin Med 8: pii: E288, 2019

20. Hermann A, Liebau S, Gastl R, Fickert S, Habisch HJ, Fiedler J, Schwarz J, Brenner R and Storch A: Comparative analysis of neuroectodermal differentiation capacity of human bone marrow stromal cells using various conversion protocols. J Neurosci Res 83: 1502-1514, 2006.

21. Zheng B, Wang C, He L, Xu X, Qu J, Hu J and Zhang H: Neural differentiation of mesenchymal stem cells influences chemotactic responses to HGF. J Cell Physiol 228: 149-162, 2013.

22. Mollinari C, Zhao J, Lupacchini L, Garaci E, Merlo D and Pei G: Transdifferentiation: A new promise for neurodegenerative diseases. Cell Death Dis 9: 830, 2018.

23. Fujimoto Y, Abematsu M, Falk A, Tsujimura K, Sanosaka T, Juliandi B, Semi K, Namihira M, Komiya S, Smith A and Nakashima K: Treatment of a mouse model of spinal cord injury by transplantation of human induced pluripotent stem cell-derived long-term self-renewing neuroepithelial-like stem cells. Stem Cells 30: 1163-1173, 2012.

24. Song CG, Zhang YZ, Wu HN, Cao XL, Guo CJ, Li YQ, Zheng MH and Han H: Stem cells: A promising candidate to treat neurological disorders. Neural Regen Res 13: 1294-1304, 2018.

25. Gancheva MR, Kremer KL, Gronthos S and Koblar SA: Using dental pulp stem cells for stroke therapy. Front Neurol 10: 422, 2019.

26. Zhang B, Gaiteri C, Bodea LG, Wang Z, McElwee J, Podtelezhnikov AA, Zhang C, Xie T, Tran L, Dobrin R, et al: Integrated systems approach identifies genetic nodes and networks in late-onset Alzheimer's disease. Cell 153: 707-720, 2013.

27. Soldner F, Hockemeyer D, Beard C, Gao Q, Bell GW, Cook EG, Hargus G, Blak A, Cooper O, Mitalipova M, et al: Parkinson's disease patient-derived induced pluripotent stem cells free of viral reprogramming factors. Cell 136: 964-977, 2009.

28. Hess DC, Wechsler LR, Clark WM, Savitz SI, Ford GA, Chiu D, Yavagal DR, Uchino K, Liebeskind DS, Auchus AP, et al: Safety and efficacy of multipotent adult progenitor cells in acute ischaemic stroke (MASTERS): A randomised, double-blind, placebo-controlled, phase 2 trial. Lancet Neurol 16: 360-368, 2017.

29. Altman J and Das GD: Autoradiographic and histological evidence of postnatal hippocampal neurogenesis in rats. J Comp Neurol 124: 319-335, 1965.

30. Sorrells SF, Paredes MF, Cebrian-Silla A, Sandoval K, Qi D Kelley KW, James D, Mayer S, Chang J, Auguste KI, et al: Human hippocampal neurogenesis drops sharply in children to undetectable levels in adults. Nature 555: 377-381, 2018

31. van Praag H, Kempermann G and Gage FH: Running increases cell proliferation and neurogenesis in the adult mouse dentate gyrus. Nat Neurosci 2: 266-270, 1999.

32. Spalding KL, Bergmann O, Alkass K, Bernard S, Salehpour M, Huttner HB, Boström E, Westerlund I, Vial C, Buchholz BA, et al: Dynamics of hippocampal neurogenesis in adult humans. Cell 153: 1219-1227, 2013.

33. Eriksson PS, Perfilieva E, Björk-Eriksson T, Alborn AM, Nordborg C, Peterson DA and Gage FH: Neurogenesis in the adult human hippocampus. Nat Med 4: 1313-1317, 1998.
34. Dennis CV, Suh LS, Rodriguez ML, Kril JJ and Sutherland GT: Human adult neurogenesis across the ages: An immunohistochemical study. Neuropathol Appl Neurobiol 42: 621-638, 2016.

35. Knoth R, Singec I, Ditter M, Pantazis G, Capetian P, Meyer RP, Horvat V, Volk B and Kempermann G: Murine features of neurogenesis in the human hippocampus across the lifespan from 0 to 100 years. PLoS One 5: e8809, 2010.

36. Kempermann G, Kuhn HG and Gage FH: More hippocampal neurons in adult mice living in an enriched environment. Nature 386: 493-495, 1997.

37. Kranc W, Brazert M, Budna J, Celichowski P, Bryja A, Nawrocki MJ, Ożegowska K, Jankowski M, Chermuła B, Dyszkiewicz-Konwińska M, et al: Genes responsible for proliferation, differentiation, and junction adhesion are significantly up-regulated in human ovarian granulosa cells during a long-term primary in vitro culture. Histochem Cell Biol 151: 125-143, 2019.

38. Kranc W, Brązert M, Ożegowska K, Nawrocki MJ, Budna J, Celichowski P, Dyszkiewicz-Konwińska M, Jankowski M, Jeseta M, Pawelczyk L, et al: Expression profile of genes regulating steroid biosynthesis and metabolism in human ovarian granulosa cells-A primary culture approach. Int J Mol Sci 18: pii: E2673, 2017.

39. Kranc W, Brazert M, Celichowski P, Bryja A, Nawrocki MJ, Ożegowska K, Jankowski M, Jeseta M, Pawelczyk L, Bręborowicz A, et al: 'Heart development and morphogenesis' is a novel pathway for human ovarian granulosa cell differentiation during long-term in vitro cultivation-a microarray approach. Mol Med Rep 19: 1705-1715, 2019.

40. Bryja A,Dyszkiewicz-Konwińska M,Jankowski M,Celichowski P, Stefańska K, Chamier-Gliszczyńska A, Borowiec B, Mehr K, Bukowska D, Antosik P, et al: Cation homeostasis and transport related gene markers are differentially expressed in porcine buccal pouch mucosal cells during long-term cells primary culture in vitro. Med J Cell Biol 6: 83-90, 2018

41. Borys-Wójcik S, Kocherova I, Celichowski P, Popis M, Jeseta M, Bukowska D, Antosik P, Nowicki M and Kempisty B: Protein oligomerization is the biochemical process highly up-regulated in porcine oocytes before in vitro maturation (IVM). Med J Cell Biol 6: 155-162, 2018.

42. Ferraretti AP, La Marca A, Fauser BCJM, Tarlatzis B, Nargund G and Gianaroli L; ESHRE working group on Poor Ovarian Response Definition: ESHRE consensus on the definition of 'poor response' to ovarian stimulation for in vitro fertilization: The Bologna criteria. Hum Reprod 26: 1616-1624, 2011.

43. Kranc W, Budna J, Dudek M, Bryja A, Chachuła A, Ciesiółka S, Borys S, Dyszkiewicz-Konwińska M, Jeseta M, Porowski L, et al: The origin, in vitro differentiation, and stemness specificity of progenitor cells. J Biol Regul Homeost Agents 31: 365-369, 2017.

44. Chomczynski P and Sacchi N: Single-step method of RNA isolation by acid guanidinium thiocyanate-phenol-chloroform extraction. Anal Biochem 162: 156-159, 1987.

45. Brązert M, Iżycki D, Kranc W, Borowiec B, Popis M, Ożegowska K, Bręborowicz A, Rachoń D, Nowicki M and Kempisty B: Genes involved in hormone metabolism and cellular response in human ovarian granulosa cells. J Biol Regul Homeost Agents 33: 461-468, 2019.

46. Huang DW, Sherman BT, Tan Q, Kir J, Liu D, Bryant D, Guo Y, Stephens R, Baseler MW, Lane HC and Lempicki RA: DAVID bioinformatics resources: Expanded annotation database and novel algorithms to better extract biology from large gene lists. Nucleic Acids Res 35 (Web Server Issue): W169-W175, 2007.

47. Huang da W, Sherman BT and Lempicki RA: Systematic and integrative analysis of large gene lists using DAVID bioinformatics resources. Nat Protoc 4: 44-57, 2009.

48. Huang da W, Sherman BT and Lempicki RA: Bioinformatics enrichment tools: Paths toward the comprehensive functional analysis of large gene lists. Nucleic Acids Res 37: 1-13, 2009.

49. Walter W, Sánchez-Cabo F and Ricote M: GOplot: An R package for visually combining expression data with functional analysis. Bioinformatics 31: 2912-2914, 2015.

50. Livak KJ and Schmittgen TD: Analysis of relative gene expression data using real-time quantitative PCR and the 2(-Delta Delta C(T)) method. Methods 25: 402-408, 2001.

51. Kossowska-Tomaszczuk K and De Geyter C: Cells with stem cell characteristics in somatic compartments of the ovary. Biomed Res Int 2013: 310859, 2013.

52. Dzafic E, Stimpfel M, Novakovic S, Cerkovnik $P$ and Virant-Klun I: Expression of mesenchymal stem cells-related genes and plasticity of aspirated follicular cells obtained from infertile women. Biomed Res Int 2014: 508216, 2014. 
53. Poloni A, Maurizi G, Foia F, Mondini E, Mattiucci D, Ambrogini P, Lattanzi D, Mancini S, Falconi M, Cinti S, et al: Glial-like differentiation potential of human mature adipocytes. J Mol Neurosci 55: 91-98, 2015.

54. Zhang L, Feng T and Spicer LJ: The role of tight junction proteins in ovarian follicular development and ovarian cancer. Reproduction 155: 183-198, 2018.

55. Wissing ML, Kristensen SG, Andersen CY, Mikkelsen AL, Høst T, Borup R and Grøndahl ML: Identification of new ovulation-related genes in humans by comparing the transcriptome of granulosa cells before and after ovulation triggering in the same controlled ovarian stimulation cycle. Hum Reprod 29: 997-1010, 2014.

56. Hatzirodos N, Hummitzsch K, Irving-Rodgers HF and Rodgers RJ: Transcriptome profiling of the theca interna in transition from small to large antral ovarian follicles. PLoS One 9: e97489, 2014.

57. Takayanagi Y, Yoshida M, Bielsky IF, Ross HE, Kawamata M, Onaka T, Yanagisawa T, Kimura T, Matzuk MM, Young LJ and Nishimori K: Pervasive social deficits, but normal parturition, in oxytocin receptor-deficient mice. Proc Natl Acad Sci USA 102: 16096-16101, 2005.

58. Gutkowska J and Jankowski M: Oxytocin revisited: Its role in cardiovascular regulation. J Neuroendocrinol 24: 599-608, 2012.

59. Briones BA and Gould E: Adult neurogenesis and stress. In Stress: Physiology, biochemistry, and pathology. Elsevier 3 pp79-92, 2019.

60. Peng L and Bonaguidi MA: Function and dysfunction of adult hippocampal neurogenesis in regeneration and disease. Am J Pathol 188: 23-28, 2018

61. Yoo S and Blackshaw S: Regulation and function of neurogenesis in the adult mammalian hypothalamus. Prog Neurobiol 170 53-66, 2018.

62. Soares R, Ribeiro FF, Xapelli S, Genebra T, Ribeiro MF, Sebastião AM, Rodrigues CMP and Solá S: Tauroursodeoxycholic acid enhances mitochondrial biogenesis, neural stem cell pool, and early neurogenesis in adult rats. Mol Neurobiol 55: 3725-3738, 2018

63. Boldrini M, Fulmore CA, Tartt AN, Simeon LR, Pavlova I Poposka V, Rosoklija GB, Stankov A, Arango V, Dwork AJ, et al: Human hippocampal neurogenesis persists throughout aging. Cell Stem Cell 22: 589-599.e5, 2018.

64. Danzer SC: Adult neurogenesis in the human brain: Paradise lost? Epilepsy Curr 18: 329-331, 2018.

65. Lin YT, Chen CC, Huang CC, Nishimori $\mathrm{K}$ and Hsu KS: Oxytocin stimulates hippocampal neurogenesis via oxytocin receptor expressed in CA3 pyramidal neurons. Nat Commun 8 : 537, 2017.

66. Zimmerman EA, Nilaver G, Hou-Yu A and Silverman AL: Vasopressinergic and oxytocinergic pathways in the central nervous system. Fed Proc 43: 91-96, 1984.

67. Busch-Nentwich E, Söllner C, Roehl H and Nicolson T: The deafness gene dfna5 is crucial for ugdh expression and HA production in the developing ear in zebrafish. Development 131 943-951, 2004

68. Stoll G, Ma Y, Yang H, Kepp O, Zitvogel L and Kroemer G: Pro-necrotic molecules impact local immunosurveillance in human breast cancer. Oncoimmunology 6: e1299302, 2017.

69. Webb MS, Miller AL and Thompson EB: In CEM cells the autosomal deafness gene dfna5 is regulated by glucocorticoids and forskolin. J Steroid Biochem Mol Biol 107: 15-21, 2007.

70. Yao X, Buhi WC, Alvarez IM, Curtis LM and Rarey KE: De novo synthesis of glucocorticoid hormone regulated inner ear proteins in rats. Hear Res 86: 183-188, 1995.

71. Croes L, Beyens M, Fransen E, Ibrahim J, Vanden Berghe W, Suls A, Peeters M, Pauwels P, Van Camp G and Op de Beeck K: Large-scale analysis of DFNA5 methylation reveals its potentia as biomarker for breast cancer. Clin Epigenetics 10: 51, 2018.

72. Assou S, Haouzi D, Dechaud H, Gala A, Ferrières A and Hamamah S: Comparative gene expression profiling in human cumulus cells according to ovarian gonadotropin treatments. Biomed Res Int 2013: 354582, 2013.

73. Chen Y, Teng FY and Tang BL: Coaxing bone marrow stromal mesenchymal stem cells towards neuronal differentiation: Progress and uncertainties. Cell Mol Life Sci 63: 1649-1657, 2006.
74. Qin X, Han W and Yu Z: Neuronal-like differentiation of bone marrow-derived mesenchymal stem cells induced by striatal extracts from a rat model of Parkinson's disease. Neural Regen Res 7: 2673-2680, 2012.

75. Lilja $\mathbf{J}$ and Ivaska J: Integrin activity in neuronal connectivity. J Cell Sci 131: pii: jcs212803, 2018.

76. Loulier K, Lathia JD, Marthiens V, Relucio J, Mughal MR, Tang SC, Coksaygan T, Hall PE, Chigurupati S, Patton B, et al: betal integrin maintains integrity of the embryonic neocortical stem cell niche. PLoS Biol 7: e1000176, 2009.

77. Honda T, Fujiwara H, Ueda M, Maeda M and Mori T: Integrin alpha 6 is a differentiation antigen of human granulosa cells. J Clin Endocrinol Metab 80: 2899-2905, 1995.

78. Kolle G, Georgas K, Holmes GP, Little MH and Yamada T: CRIM1, a novel gene encoding a cysteine-rich repeat protein, is developmentally regulated and implicated in vertebrate CNS development and organogenesis. Mech Dev 90: 181-193, 2000.

79. Prenkert M, Uggla B, Tidefelt U and Strid H: CRIM1 is expressed at higher levels in drug-resistant than in drug-sensitive myeloid leukemia HL60 cells. Anticancer Res 30: 4157-4161, 2010.

80. Iwasaki Y, Shiojima T, Tagaya N, Kobayashi T and Kinoshita M: Effect of transforming growth factor $\beta 1$ on spinal motor neurons after axotomy. J Neurol Sci 147: 9-12, 1997.

81. Mira H, Andreu Z, Suh H, Lie DC, Jessberger S, Consiglio A, San Emeterio J, Hortigüela R, Marqués-Torrejón MA, Nakashima K, et al: Signaling through BMPR-IA regulates quiescence and long-term activity of neural stem cells in the adult hippocampus. Cell Stem Cell 7: 78-89, 2010.

82. Blázquez-Medela AM, Jumabay M and Boström KI: Beyond the bone: Bone morphogenetic protein signaling in adipose tissue. Obes Rev 20: 648-658, 2019.

83. Nilsson EE and Skinner MK: Bone morphogenetic protein-4 acts as an ovarian follicle survival factor and promotes primordial follicle development. Biol Reprod 69: 1265-1272, 2003.

84. Takao Y, Fujiwara H, Yamada S, Hirano T, Maeda M, Fujii S and Ueda M: CD9 is expressed on the cell surface of human granulosa cells and associated with integrin alpha61. Mol Hum Reprod 5: 303-310, 1999.

85. Hayati AR, Nur Fariha MM, Tan GC, Tan AE and Chua K: Potential of human decidua stem cells for angiogenesis and neurogenesis. Arch Med Res 42: 291-300, 2011

86. Yang Y, Ye Y, Su X, He J, Bai W and He X: MSCs-derived exosomes and neuroinflammation, neurogenesis and therapy of traumatic brain injury. Front Cell Neurosci 11: 55, 2017.

87. Virant-Klun I, Rožman P, Cvjeticanin B, Vrtacnik-Bokal E, Novakovic S, Rülicke T, Dove P and Meden-Vrtovec H: Parthenogenetic embryo-like structures in the human ovarian surface epithelium cell culture in postmenopausal women with no naturally present follicles and oocytes. Stem Cells Dev 18: $137-150,2009$.

88. Asaoka-Taguchi M, Yamada M, Nakamura A, Hanyu K and Kobayashi S: Maternal Pumilio acts together with Nanos in germline development in Drosophila embryos. Nat Cell Biol 1: 431-437, 1999.

89. Wang $Z$ and Lin H: Nanos maintains germline stem cell self-renewal by preventing differentiation. Science 303: 2016-2019, 2004.

90. Subramaniam K and Seydoux G: nos-1 and nos-2, two genes related to Drosophila nanos, regulate primordial germ cell development and survival in Caenorhabditis elegans. Development 126: 4861-4871, 1999.

91. Jaruzelska J, Kotecki M, Kusz K, Spik A, Firpo M and Reijo Pera RA: Conservation of a Pumilio-Nanos complex from Drosophila germ plasm to human germ cells. Dev Genes Evol 213: 120-126, 2003.

92. Virant-Klun I, Knez K, Tomazevic T and Skutella T: Gene expression profiling of human oocytes developed and matured in vivo or in vitro. Biomed Res Int 2013: 879489, 2013.

93. Julaton VT and Reijo Pera RA: NANOS3 function in human germ cell development. Hum Mol Genet 20: 2238-2250, 2011.

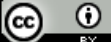

This work is licensed under a Creative Commons Attribution 4.0 International (CC BY 4.0) License. 